Mariusz Jastrząb

e-mail: mariusz.s.jastrzab@gmail.com

\title{
Issues concerning relations between business and society in teaching Business History in the United States and Poland"
}

\begin{abstract}
Based on empirical material in the form of case studies prepared at Harvard Business School and Kozminski University, the article analyses the content of teaching materials in the field of business history. The Harvard case studies served as a model for the Polish ones. In contrast to the United States, at Kozminski University and in other Polish business schools, business history is not taught as a separate subject.

The article puts forward the thesis that history education could provide an opportunity for future managers to broaden their knowledge of the social environment in which they will operate and to shape attitudes of responsibility for the social consequences of decisions made. However, this opportunity remains largely untapped in both the United States and Poland. American teaching materials are still influenced by the Chandlerian paradigm, and therefore they focus on the evolution of structures and changes in the strategy of large multinational corporations. These materials present students with role models of successful entrepreneurs and companies. Their social environment is presented in a sketchy manner, and questions about the motivations of human actions or hierarchies of values are rarely asked. The teaching materials also shy away from questions about the social consequences of managerial decisions. This is so, despite the fact that scientific publications are moving away from concentrating solely on the centre of global capitalism, the history of the largest corporations, and the treatment of the social environment as a variable on which the entrepreneur or company have no influence. Business history as a scientific discipline in Poland is still at an early stage
\end{abstract}

\footnotetext{
* The article is an updated and extended version of the paper published in Polish in the Annales. Ethics in Economic Life, 16, 63-74.
} 
of development. However, one can notice a gap between research and teaching similar to the one that exists in the USA: there are works critically analysing the period of transformation and showing the peripheral character of Polish capitalism as well as the social consequences of this peripheral nature that are completely ignored in teaching.

Keywords: business history, Harvard Business School, Kozminski University, management education

JEL Classification: L21, M14, N80

\section{Introduction}

The critics of the presentistic character of modern management education postulate a wider consideration of the historical perspective. They see this as a way to sensitise business managers to the long-term social consequences of their decisions and to make them aware of the responsibility for the achievements of their predecessors, the fate of their employees and the communities in which they operate (Górski, 2007, p. 27; Ratajczak, 2011, pp. 18-20). More comprehensive historical knowledge would prevent managers from accepting excessive risk and applying a short-term profit orientation, provide them with the ability to analyse the environment, anticipate actions of particular company stakeholders, identify potential conflicts and solve them (Sobczak, 2010). This knowledge should also sensitise them to the role of cultural and social factors in activities undertaken by individuals and groups, and also make them aware that the motivation of human actions cannot be reduced solely to the pursuit of profit (Duda, 2008).

Teaching history is also a way to create among managers the attitude of activism, openness to social needs, and readiness to respond to them. The past would provide positive personal role models. Examples of former entrepreneurs and companies could show that adherence to high ethical standards proves to be profitable in the long term (Marks \& Skodlarski, 1995). History, along with other humanities, would not only expand students' general knowledge and build a foundation on which they would be able to acquire specialist knowledge but it would also help to develop the ability to look at the company's activities in the context of the entire economy and solve unusual problems. It would teach students to think in a non-schematic manner to prepare them to make decisions, not just to perform executive functions in the enterprise (Chłopecki, 1999; Kluska, 1999, p. 208; Morawski, 2008, p. 16). Historians would like future managers to treat historical knowledge as a key to understanding the present and as an important analytical tool that would allow them to aptly forecast the future, thus reducing uncertainty (Matera, 2006). 
The interest in the past, however, is not fostered by rationalistic, technocratic concepts in management sciences, arising from the spirit of positivism and originating in the 19th century, in the period of formation of management as a scientific discipline. An inherent part of those concepts was the conviction that it was possible to develop universal decision-making rules, consciously and basically freely shape organisational structures of enterprises based on the efficiency criterion, and manage employees that would share the efficiency orientation, and thus react in a predictable manner to stimuli. The consequence of such thinking is the presentism mentioned earlier, the belief that the legacy of the past is not important from the point of view of the present and the future of the organisation (Górski, 2009a, 2009b, p. 110). What partially contributes to overcoming such an approach is the growing interest on the part of management specialists in organisational culture, mechanisms of remembering and forgetting that function within the organisation, the state of awareness of its participants, their value systems, emotions, and ways of defining the situations in which they found themselves, factors affecting the course of organisational change processes, or constraints faced by management boards when making strategic decisions.

In the article, I would like to analyse selected case studies prepared (i.e. written or corrected) in the years 2010-2012 at Harvard Business School and presented to students as part of business history classes. I will attempt to show how the relationships between business and society are described in these classes. I will be interested in exploring whether students are inclined to discuss moral dilemmas resulting from strategic decisions made by managers. Are they persuaded to think about how such decisions influenced the fate of various groups of company stakeholders? What does the issue of managers' responsibility look like: is it treated as an obligation to only focus on owners' profits or are wider responsibilities considered? Is there a place to reflect on how a responsible entrepreneur should behave in a poor country or in a country with an undemocratic system?

The standards at Harvard are important because this university sets trends in the field of management education and is a role model for others. This is also where business history was born as a scientific discipline.

My goal will also be to look at the attempts of transplanting American models onto Polish soil. The subject of the analysis will be case studies prepared by the employees of Kozminski University as part of the project Sources of Social Capital in Organisational Management Practices, implemented between 2013 and 2017, and financed by the National Centre for Research and Development. We are undoubtedly dealing with a situation of cultural transfer: the American case studies served as a model for the participants of the Polish project. This is evident even in the layout of the texts: they usually start with the lead in, calculated to arouse the interest of the reader, and are supplemented with illustrations or statistical materials. The lecturers are offered teaching notes. Therefore, it is reasonable to ask to what extent Polish authors adopted the approach to social issues from the American prototype. Did they try to introduce future managers, who are supposed to operate in Poland, to issues specific to the region located on the periphery of the global economy? 
The manner of treating social and ethical issues in teaching seems to be related to the evolution of business history as a field of knowledge. I will start with a brief presentation of its development in the world and in Poland.

\section{What is business history? ${ }^{1}$}

Business history explores the history of companies or entire industries and people related to business (owners, managers, employees) (Jeremy \& Tweedale, 2005, p. xiii). It originated in the 1920s. In 1927, Harvard created the world's first Department of Business History. It was chaired by Norman S.B. Gras, a historian dealing with, among others, the history of English customs policy and the grain market as well as American banking. One year before Harvard's professorship, Gras became the editor of "Business History Review" (originally under a different title), the first scientific journal specialising in the history of enterprises. The first association of business historians was also established at Harvard (Barker, Campbell \& Mathias, 1960, p. 23; Galambos, 1967, p. 1). Initially, business history was practised only in the United States. After the Second World War, it also became the subject of interest in Western Europe and Japan. The research focused on the internal history of companies, mainly the largest ones that operated globally, and on the biographies of leading businessmen.

The development of research on the history of enterprises resulted not only from the interests of people employed at universities but also from the needs of business circles. Before business history made its way to universities, and subsequently parallel with academic research, journalists, retired managers, or professional historians hired for such a task, wrote stories of large enterprises on behalf of their management. Those projects were usually occasional ones, typically associated with the celebration of anniversaries important for the companies. Such stories served to cultivate a positive image, and probably played a role in building their organisational cultures. However, the stories were also important for the way that business history was practised at universities: they strengthened the trend to deal mainly with the largest companies and write about them in a positive context.

The work of the most important representative of this field of knowledge, Alfred Chandler $(1962,2002)$, contributed to the consolidation of the tendency of business history to focus on the history of large corporations originating from the centre of world capitalism, i.e. from the United States or Western Europe. Chandler led to the situation in which business history went beyond the Departments of Management, and historians studying other aspects of social life became interested in it. He wrote about American railway companies, steel producers, oil, automotive, armaments, and chemical companies, as well as large commercial enterprises. He pointed to factors, primarily technical ones, which, from the second half of the

\footnotetext{
${ }^{1}$ In the reconstruction of the development of business history as an academic discipline in this part of the text, I rely heavily on my article Historia biznesu: czego uczy i czy pomaga zrozumieć światowy kryzys? (2011).
} 
$19^{\text {th }}$ century, enabled them to develop quickly. He believed that the United States and Western Europe owed their economic growth to the activities of large corporations and that they were the ones that determined technical progress. He presented both the circumstances in which the management of large companies became professionalised and the consequences of this process.

In Chandler's opinion, large corporations began to play a special role in the modern economy. Although the market continued to create a demand for goods and services, corporations became the coordinator of their flow; they also began to decide on the allocation of human and financial resources, thus determining the directions of economic development (1962, p. 1). Chandler's theses were criticised. He was accused of being schematic and deterministic - of providing a onedimensional explanation of organisational changes based on technological factors, and ignoring the socio-cultural context of management evolution (Colli, 2003, pp. 9-10; Usselman, 2006, pp. 584-596). Despite the criticism, the explanation model proposed by Chandler strongly influenced further research and how business history is taught. Chandler's research focused on the strategy of large companies and the evolution of their organisational structures in response to changing market conditions. This aspect of his work has been inspiring for management specialists (Koźmiński \& Latusek-Jurczak, 2011, p. 57). Chandler's successors followed in his footsteps: they analysed the strategy of the large companies and the organisational changes taking place within them. They devoted less attention to the relationship between business and its environment.

The impulse that stimulated the interest in relationships between the present and the past of companies was provided by the history and memory-related turn in research on organisations to which the works of Craig E. Carroll, Michael Rowlinson, and Charles Booth (2009) contributed. It transferred the point of reflection from attempts to recreate the past of the organisation to the study of how this past is remembered, portrayed, or forgotten today, and what goals the creation of various images of the past can serve. The development of this trend of research was associated with the already mentioned increase in the popularity of organisational culture issues among management specialists, but it also fit in with the interest in the subject of the discourse developed on the basis of various social sciences. It was also a response to the accusation aimed at more traditional business history that it was only descriptive. Works that are situated in the mainstream of organisational history are rooted in sociological theories and draw from the stock of terms and theoretical concepts created by anthropologists. These studies also undertake a source-based reflection: they analyse the nature of archival materials created by companies or the impact of the passage of time and changes in the current situation of employees on the way they talk about their past.

Business history began to be taught at Harvard after Gras took the chair. In the 1970s, Alfred Chandler and his colleagues introduced the Coming of Managerial Capitalism course into the curriculum, and its main subject, in line with Chandler's interests, became the professionalisation of management-its causes and impact on various aspects of economic life. It is still offered to students today (McCraw, 1999, pp. 154-156). 
The popularity among students of the course on the evolution of managerial capitalism resulted in the development of another course in 1996, compulsory for everyone starting the MBA programme: Creating Modern Capitalism. How Countries, Companies and Entrepreneurs Triumphed in Three Industrial Revolutions. It systematically presented the formation of the capitalist economy in Great Britain, Germany, the United States and Japan, and discussed the history of two large companies from each of those countries to illustrate the economic processes taking place there (McCraw, 1999, p. 157).

That subject was later removed from the programme, but it was replaced by a history course, offered as an elective subject, titled Entrepreneurship and Global Capitalism. It concentrates on how entrepreneurs built a global economy in the $19^{\text {th }}$ century, creating organisations capable of operating in distant markets and transferring resources across national borders, and then how the trend towards the globalisation of the economy turned during the World Wars and the Great Depression. One of the modules of this subject is about how entrepreneurs contributed to the reconstruction of international economic ties after the Second World War. And another one-how India, China, Brazil and Russia and the countries of the former Eastern bloc have been incorporated into the orbit of this economy in recent decades. Therefore, the analysis of historical events should help students understand the opportunities open to contemporary entrepreneurs and the risks that the authors of the course see in recent trends of deglobalisation.

Harvard Business School also offers Creating Modern Financial System classes, which concern the development of markets and financial instruments, financial intermediation, and changes in human behaviour related to the sphere of finance. The classes chronologically cover the period from the end of the $18^{\text {th }}$ century to the present. They devote a great deal of space to the United States, although they also pay attention to phenomena characteristic of other countries. Historians also co-create and co-run obligatory classes devoted to Government Economic Policy, Business, Government and International Economy. In addition, a doctoral seminar on business history is offered.

There is quite a large number of history classes at Harvard. None of these classes is of a systematic, chronological lecture type. The history of certain companies is chosen, and some of the problems they faced in the past are selectively presented, to give students the opportunity to analyse them using the tools and concepts they have become familiar with while studying other subjects. The classes focus on the period from the beginning of the industrial revolution to the present day, and the peripheral areas in the global economy are the subject of their interest almost exclusively from the perspective of the expansion of large international corporations.

In Poland, business history as a separate subject is not taught, apart from elective courses (at the University of Warsaw, such classes were taught by Tomasz Ochinowski). There is the Institute of Sociology of Organisation and Business History at the Faculty of Management of the University of Warsaw headed by Prof. Ochinowski, but it cannot be said that an established scientific community dealing with this issue exists. There is a tradition of research into the history of 
enterprises conducted by economic historians which dates back to the time of real socialism. Management specialists taking into account the historical perspective in their research are aware of this tradition, but they do not refer to it more broadly. They rarely undertake research based on archival material. Karolina Mikołajewska-Zając from Kozminski University uses the oral history method in her articles. However, it is an exception. A large part of Polish empirical work is based solely, or almost solely, on published business memoirs and printed corporate stories.

Among the problems raised in Poland, the issue of factors conducive to the longevity of the organisation occupies an important place. Authors of works in this field, in the spirit which is characteristic of management sciences, make attempts to build certain classifications to detect regularities and common features of companies that existed for dozens or even hundreds of years, or which still exist today (Pikos \& Olejniczak, 2017, pp. 55-77; Witek-Crabb, 2017, pp. 157-167). The subject itself is interesting. Enterprises operating in Poland seem to be an interesting object of analysis. However, due to the course of Polish history, it is important to adopt in such research precise assumptions about what organisational continuity really means: existing enterprises often refer to the tradition of companies from which they did not inherit employees, brands, markets, physical property or any intellectual capital components. Reference to the legacy of an entity with a long history may be an important element of the organisational culture of a contemporary company, presenting itself as the heir, yet it is not this kind of business survival that the students of determinants of longevity should be really interested in (Pikos \& Olejniczak, 2017, pp. 55-77).

In Poland, studies are also conducted that treat the traditions of entrepreneurship as a source of values and good practices that allow us to solve problems occurring today. Writing on this subject, Prof. Ochinowski (2013) focuses on the history of small companies and shows that their owners in many cases-when they fought for their market share, faced crises or tried to establish relationships with employees - faced similar dilemmas as modern entrepreneurs. Intellectually provocative, though probably without a chance to be introduced into the mainstream of both management and history sciences, there is also an attempt by Professor Ochinowski (2005, pp. 7-20) to use the conceptual apparatus and theoretical achievements of management sciences to analyse the course of an important historical conflict: the rivalry between the Catholic Church and the communist party at the local level in post-war Poland.

The memory studies trend is present in Polish research. Reflections are taken on creating, negotiating, transforming, and manipulating the memory of the past within the organisation, especially in the context of organisational changes (for example, changes resulting from the systemic transformation) (Mikołajewska-Zając, 2017, pp. 45-72). Karolina Mikołajewska-Zając and Joanna Wawrzyniak (2016, pp. 36-54) have analysed nostalgic stories about Jan Wedel. The official version of this story was intensively used by the then owner of Wedel, the Cadbury company, in the first decade of the $21^{\text {st }}$ century, to build the image of contemporary Wedel as a socially responsible company, caring for its employees, and a family-run business that uses the skills of highly qualified confectioners and craftsmen. Due to the fact 
that it was a period of employment reduction and problems for the owner of Wedel, the workers constructed a "counter-story" in which the vision of the pre-war "golden age" of the factory under the rule of an enlightened but stern owner was used to delegitimise contemporary reality (2016, pp. 36-54). In another article, also based on empirical material concerning Wedel, Karolina Mikołajewska analysed the discourse regarding the privatisation of the enterprise. What is very interesting in this context is the treatment of not only regular employees but also (post-)socialist managers of state-owned enterprises as a marginalised group losing its influence at a time when Polish companies were starting to take on the global market. Drawing attention to the fact that no economic system, even free market capitalism, is accepted as natural is also an interesting aspect of this research. Its introduction requires individuals to develop a new conceptual apparatus, redefine their professional roles, change the way of thinking about key competencies, as well as to provide new answers to questions about what lies in the interests of the organisation and various social actors associated with it, which of these interests should be pursued, and what methods should be used to do so (Mikołajewska, 2014, pp. 69-80).

\section{Case studies}

A characteristic element of the business history curriculum at Harvard Business School is the use of the case studies method, practised since the beginning of the presence of the subject at this university. Preparing case studies was and is one of the most important duties of historians employed at Harvard.

The case studies presented to students encourage them to analyse specific strategic decisions made by entrepreneurs. They often raise issues of the activities of large companies from Western Europe and the United States in the markets of underdeveloped countries. However, they do not discuss the problem of using double standards - high in the home market and low in a poor country - in relation to working conditions, product quality or environmental protection. External determinants are treated as data which are independent of the company. Entrepreneurs are not required to change the world for the better. Their mission is to maximise profit in the social and political conditions that others have created for them. Companies are not expected to pursue the ethical maximum. They should comply with the legal requirements of the country in which they operate, pay employees' salaries corresponding to local market conditions, even if they are very low, and not to treat them worse than competitors do. Let us refer to some examples: Geoffrey Jones and Lisa Bud-Freirman present the activities of Weetman Pearson, an entrepreneur from Great Britain who, from the late 1880s, carried out large construction contracts in Mexico and was involved in the exploitation of local oil deposits. The background is the situation in the global oil market before World War I, the turbulent history of Mexico, and international politics: the USA's efforts to protect the interests of American companies and the country's political influence in Mexico as well as the complications associated with it in relations 
with Great Britain. The authors mention the inequalities prevailing in Mexico, modernisation programmes that the local authorities tried to implement, as well as social conflicts, and the rise of nationalism. However, these issues are treated marginally, and nobody attempts to answer the question about their causes. Pearson, favoured by the Mexican authorities during the dictatorship of Porfirio Diaz, was one of the most important foreign investors operating there. However, the authors do not encourage students to discuss how he gained such a position or whether his treatment of employees increased or reduced social tensions, or how Pearson's company dealt with local communities. The task of the students is to assess whether Pearson should have sold his profitable Mexican business when the state decided to nationalise natural resources or if he should have stayed in Mexico, despite the unfavourable development of the political situation from his point of view. The social effects of the entrepreneur's activities are not of interest (Jones \& Bud-Freirman, 2010, pp. 1-11).

A case study describing the activities of the Guggenheim family in Chile is constructed in a similar manner. At the end of the 19th century, a company belonging to them began to exploit the deposits of silver, and then copper and nitrate. The authors are interested in the relationships between the government of a poor country, dependent on the exports of its mineral wealth, and large entrepreneurs. Another important issue is what consequences the rapid development of chemical technology-which allowed, among others, for the cheap synthesis of ammonia and nitric acid which had been previously obtained from nitrate- had for the company involved in the exploitation of natural resources. The authors are not interested in the gap between the behaviour of the businessmen in the USA, where the Guggenheims were known for charity and numerous social initiatives, and their attitude in peripheral countries such as Chile and Mexico, where they did not take similar steps and kept wages at a level barely covering the minimum needs (Jones \& Fernandes, 2012, pp. 4-14).

In the case study concerning less distant history, i.e. the period after World War II, depicting the history of the United Fruit Company and its activities in Colombia, the problem of the company paying paramilitary groups operating there arises. However, this is not a question of a moral nature, but related to the fact that since 1977, American law has banned such practices. Students are faced with the question of how to stay in line with American regulations, not to expose the company's image to harm, and at the same time be competitive when competitors have no qualms about paying bribes and when the refusal to do so may endanger the safety of employees. It is characteristic, however, that no withdrawal from the market is considered (Mead, Wicks \& White, 2010, pp. 1-11).

The case study concerning the economic crisis in Dubai in 2008-2009 takes as its starting point the history of this city since the arrival of the British. It deals with the impact of the discovery of oil resources on its development, and then with the activities that make Dubai independent from the proceeds from oil extraction. The activities include the development of maritime and air transport as well as tourism, and the creation of incentives to invest for companies from the financial sector and related to media and advertising. The authors also describe social rela- 
tions in Dubai: the inflow of the workforce from abroad, and mechanisms of controlling employees and inducing them to leave quickly for home in the event of them losing their jobs. Questions about the social consequences of such a development model are not posed. There is also no attempt to seek an answer to the question of whether it was possible to adopt a more sustainable option, burdened with less risk, and why it was not done. Students must simply consider what the family governing Dubai should have done to help the city overcome the crisis (Maurer, 2011, pp. 1-6).

Harvard Business School students also come into contact with case studies regarding business activity in totalitarian regimes. The discussion concerning the operation of the Beiersdorf company, the manufacturer of Nivea cream, under Hitler's government, is aimed at discussing the legal ways to protect the company from political risk. Ethical aspects of activities related to its "Aryanisation" are not considered. It is noted that in the 1930s, its promotional activity was adapted to the Nazi propagation of femininity and the ideal of Germanism. However, this is presented as a necessity (Jones \& Lubinski, 2011, pp. 9-15). A similar study was made about the activity of the IBM company in Nazi Germany. According to its authors, the company had to maintain proper relations with the authorities as it obtained orders from the government, and engaged in anti-Jewish activities only as much as it was inevitable (Jones \& Brown, 2011, pp. 7-8). The case studies seem to confirm the thesis put forward by the authors of the works created several years ago, on the wave of research related to the high-profile claims of victims of the Third Reich. Usually, those works prove that the managers were trying to adhere to common practices and run their business as usual. If they used the work of forced labourers, it was because they had no other choice. If they took over companies belonging to "non-Aryans", they tried to treat their owners in a humane way. If they fulfilled armament orders, it was only because they could not refuse to accept the authorities' orders, and their enterprises were harnessed in the mechanisms of state economic planning. If they joined the German Nazi Party, they usually did it for the good of the company, not out of their true conviction (cf. e.g.: Feldman, 2001; Turner, 2005).

The case studies described here are characterised by a strong biographical orientation. The authors are happy to draw portraits of successful entrepreneurs. In the spirit of corporate culturalism, they are presented as characters whose personalities proved to be crucial for shaping the company's organisational culture (Ludescher \& Burgelman, 2012, pp. 2-15). Not everyone was irreproachable, but the case studies avoid ethical evaluation. If the entrepreneurs described careers built on bribery or black market operations, or if they used market shortages, the forced position of contractors or their monopolistic positions to obtain exceptionally high profits, this is presented as a result of circumstances beyond their control, resulting from conditions in which they happened to be operating. The state is often indicated as the entity responsible for their creation. It is emphasised that the behaviour of the described people did not differ from the norm adopted at a given time and place. Their competitors acted in a similar manner (Koplan \& Jones, 2011, pp. 1-18). 
One of the businessmen presented to students is Rupert Murdoch. The history of his family can be traced back to the interwar period, and the first investments in press titles and radio stations made by his father, up to the present day. The authors of the study write about the controversy regarding Murdoch: the political involvement of his media outlets and the allegations that he transformed the acquired press titles into tabloids full of gossip, eroticism and brutality. They mention accusations of failure to keep promises and dishonesty in dealing with business partners or the ruthless treatment of employees. Again, however, these problems are not of interest to the authors of the study devoted to Rupert Murdoch. For them, the issue of the family maintaining control and the effective management of a large media corporation is important (Jones \& Ishna, 2012, pp. 2-15).

The case study devoted to Werner von Siemens discusses in detail his investment in the construction of telegraph networks begun in the $1840 \mathrm{~s}$. His case was chosen to show students the risks associated with investing in new and unreliable technologies. It is also used to ask questions about the opportunities and dangers arising for companies from the fulfilment of government orders and changing legislation. Telegraphic communication, due to the political and military importance of the possibility of sending information speedily at a distance, became the subject of regulation, including international laws, soon after its birth. What is characteristic, however, is a lack of reflection on the methods of acquiring government orders. It is mentioned that Siemens relied on personal contacts with influential people. It is also said that when investing in Russia, the company was forced to buy the favour of tsarist officials. However, it is mentioned only marginally and is not treated as a problem, but as an element of a rational strategy of action. The authors suggest that the entrepreneur made the right decision to enter the Russian market, as due to the size of the country and the poor development of infrastructure, it opened huge opportunities to create communication networks, and having entered, the company had to accept the rules of the game, including corruption (Jones, 2011, pp. 7-18).

The case study devoted to John D. Rockefeller even mentions the morally questionable methods of competition that he used: secret agreements with railway companies thanks to which he cut off competitors from oil supplies and obtained tariff discounts for Standard Oil, buying information about oil transportation to independent refineries, intimidating customers, and hindering the distribution of their products. The analysed case study, however, deals primarily with the problem of the progressing concentration in the American oil industry and changes in Standard Oil's organisational structures. The authors draw attention to Rockefeller's adaptation of the legal institution of trust, previously functioning in family law (a council managing the assets of an orphaned minor child), to manage a large economic organisation. This allowed for the non-disclosure of key information to the authorities and the hiding of links between Rockefeller-controlled companies. Conducting such activities is presented as ethically neutral. They are explained in terms of the businessman's rational response to the restrictions imposed by American antitrust laws that were created in his time. At the same time, the study concerning Rockefeller, like other biographies of great businessmen, devotes a great 
deal of space to his upbringing and family situation. The sources of his business decisions, including those related to social involvement, are sought in psychological factors (Koehn \& Miller, 2010, pp. 1-3, 21-30).

The exception is the case study showing the activities of Bono, the leader of rock band U2, against the development of the music market in Europe and the United States over the last fifty years. It broadly discusses his activities to combat hunger in Africa, the fight against apartheid and racism, the support provided to Amnesty International and the charitable actions undertaken in connection with the war in Yugoslavia. Above all, however, it shows ways of gaining political support for the idea of debt relief for the poorest countries in the world and for gaining financial resources to fight AIDS and contagious diseases in Africa. The authors of the study also do not shy away from asking questions about the influence of the social activities of the leader on the functioning of the band in the music market (Koehn, Miller \& Wilcox, 2011, pp. 10-41).

The study devoted to Sarah Breedlove (Madam C. J. Walker) is also distinctive among the other case studies. She was a daughter of slaves, worked as a laundress and cook in her youth, and in 1906, founded a company that produced hair care products. The authors analyse the environment in which she operated, indicating the moral, legal and economic constraints that she had to overcome. At the same time, they write about her commitment to the black community, i.e. inducing the agents through which she sold her products to organise charity campaigns, organising self-help and support for black immigrants from the South to the cities of the North of the United States, and trying to get the representatives of the black population to influence American foreign policy (Koehn et al., 2011, pp. 15-28). Therefore, the case of Madam C.J. Walker opens the field for discussion on many important social problems: solidarity and racial barriers, the organisation of selfhelp institutions, mechanisms of social advancement, or determinants of the economic success of people from discriminated groups.

Between 2013 and 2017, employees of Kozminski University-Dominika Latusek-Jurczak, Justyna Starostka, Kaja Prystupa-Rządca, Tomasz Olejniczak, and Anna Pikos - created a database of case studies modelled on the Harvard ones. It also contains case studies related to business history. The database is linked with its American prototype through its strong biographical orientation: people are usually in the centre of the story - the Jabłkowski family, the Wedel family, or the founder of the Pruszkow pencil factory, Stanisław Majewski. This, although scientifically questionable, may be their teaching advantage: there is a chance that these people's stories will interest students. Unfortunately, the historical narrative of Polish case studies is often based on one study, which is not always a result of in-depth research. The authors do not usually verify the information contained therein. They do not always critically analyse official corporate stories or the reminiscences of entrepreneurs on which they are often based, which results in inaccuracies. It can be assumed that from the point of view of teaching goals, they usually do not have a significant meaning. However, without going beyond the information derived from a single study, usually concerning the history of the company, it is impossible to explain to students in a comprehensible way 
the reasons for a given company's transformation, and, in particular, how it was influenced by the external environment. A good example is the case regarding the porcelain factory in Ćmielów. Students do not learn from it why the production plant operated as a magnate manufactory for over half a century (between 1809 and 1863), or what led to its transformation into a capitalist factory. Although the aim of the study is to discuss the topic of building and positioning the brand, there is no information to understand how the company has developed a portfolio of production patterns which today have become an important factor of its competitive advantage. It is not clear how the capital of knowledge and skills was preserved in the process of privatisation and changes in the transformation period. Cooperation with the Institute of Industrial Design is mentioned in a cursory manner. It can be assumed that the average student will not know what the significance of the Institute for the development of modern design in Poland during the post-Stalin period was (Starostka, Olejniczak \& Pikos, 2016).

The Polish case studies place a stronger emphasis on explaining the longevity mechanisms of enterprises than the American ones. It is not surprising because, as I mentioned above, this is one of key subjects of research conducted in Poland and because due to the turbulent character of Polish history, the long existence of a company is the exception rather than the rule. In spite of this fascination with longevity, the authors of the studies leave gaps-some periods and issues are presented in a very sketchy way or not mentioned at all. Usually this concerns periods and issues that are difficult to unambiguously assess, controversial, not praise-worthy, and not a part of the organisation's internally authorised story of a good past filled with success and hard work. The studies follow in this area the sources of information they are based on. Also, repeating the narrative of the sources, the period of systemic transformation is usually depicted as a time of deindustrialisation: the collapse of industry caused by foreign investors taking over plants. By repeating the opinions contained in official corporate stories, the Polish authors gladly write success stories. In their case studies, they show the described plants as modern, not worse than western ones, and managed in accordance with the highest standards in force at the time.

These phenomena are clearly seen based on the example of the history of the Fasing group, a Silesian manufacturer of mine equipment and chains for mining machines with a hundred-year tradition, which was analysed by Tomasz Olejniczak and Kaja Prystupa-Rządca. It would seem to be fascinating material for discussions about the interweaving of Polishness, Silesianness and Germanness, the impact of political changes on the enterprise, but also about organisational memory and collective forgetfulness. The study, however, does not mention at all ethnic issues or changes in Silesia's national status. During World War II, the company was taken over by German management and worked for the army. This period, however, is merely mentioned in the official corporate history and the case study analysed here. Following the publication prepared by Fasing on the occasion of its one hundredth anniversary, and thus containing an official version of the company's history sanctioned by the management, which is also in line with the narrative found in books or articles aimed at motoring enthusiasts, the authors tell the story of the engineer 
Gustaw Różycki, the pre-war owner of one of the plants which later became part of the group, as an important topic of study. The undertaking of small-scale production of motorcycles by the engineer is presented as a success story, although, in fact, regardless of the engineering talent of Różycki, the applied methods and scale of production testify to the peripherality of the Polish automotive industry in the 1930s. The period of real socialism is mentioned in turn as a time of export development, primarily in the markets of socialist countries, and the expansion of the company's own research and development facilities. The 1990s, also following the official history of the company, is presented by the authors as a period of Polish enterprises being acquired by their western competitors in order to liquidate companies. Fasing supposedly avoided that fate thanks to its division, which made it possible for the enterprise to be acquired by domestic investors who were weaker in terms of capital. The $21^{\text {st }}$ century is associated with a decision about the specialisation in the production of chains, the acquisition of its largest German competitor, and expansion into foreign markets, which made the Fasing Group one of the world's leading companies. Thus, the study shows how a company which did not manage its human resources very economically and imitated western technological ideas, in a manner characteristic of an underdeveloped region, has managed to avoid the dependence on its development path to become the leader of the global market (Olejniczak \& Przystupa-Rządca, 2016).

In the initial paragraph of the case study devoted to the Department Store of the Jabłkowski brothers, the authors stated:

In today's Polish consciousness, department stores are most often associated with not very attractive tin lumps of the socialist era which constitute a dubious decoration of the centre of Warsaw. Contrary to appearances, however, pre-war Warsaw did not lag behind global trends and was able to boast two department stores famous across the entire Eastern European region - the department stores of Herse and the Jabłkowski brothers. (Olejniczak \& Pikos, 2017, p. 1)

The very fact that the department stores, many of which are icons of Polish modernist architecture, are for the authors "tin lumps of the socialist era" is probably a reflection of the state of their historical consciousness - thinking about the period of People's Poland as a time of absurdities and discontinuation-a forced break in what they probably regard as a norm in business operations, i.e. the functioning of enterprises in market conditions. This quote, however, first of all signals that they want to write about the history of the Jabłkowski family as a success story whose leading premise is the creation of a company similar to western ones. In fact, the Jabłkowski Brothers Department Store was smaller and operated according to slightly different rules than its western counterparts, although the owners used ideas that were applied there. The basic question about the Jabłkowski Brothers Department Store should, therefore, be related to how the patterns of western large-surface trade were adapted to Polish conditions and why not all foreign ideas could be implemented. The problem of managing a company in a crisis situation, in response to a shock, is also interesting: after all, the Jabłkowski Brothers company operated in the period of World War I, post-war hyperinfla- 
tion, the recession caused by Władysław Grabski's stabilisation programme, the Great Depression of the 1930s, and World War II. The Department Store operated under favourable conditions for only a few years.

The authors write about how the Jabłkowski brothers built good relations with their employees. However, the personnel management was characterised by many features of paternalism. It seems that the case study should treat the topic more broadly, including the issue of delegating rights to employees responsible for individual departments and changes in management mechanisms during the transformation of the Department Store from a family business into a large enterprise.

The study pays a great deal of attention to the efforts that eventually led to the reactivation of the company and the recovery of its building after the collapse of real socialism. However, the authors write little about the memory of the brand that survived the period of People's Poland. Meanwhile, the durability of this memory and its evolution are extremely interesting: in the official circulation, until the 1980s, there were no messages supporting the memory of the Jabłkowski family, and yet the residents of Warsaw spoke about their department store. In addition, the company actually served customers belonging to the middle classes, but in the memory of subsequent generations, probably not unrelated to the experience of the socialist deficit economy, the store has become an enterprise selling luxury goods. The passage cited above shows that the authors of the study have also succumbed to this illusion.

Tomasz Olejniczak, a co-author of the study about the Jabłkowski Brothers Department Store, takes up the problem of the peripheral development of Polish industry in the case study comparing the history of the car factory (Fabryka Samochodów Osobowych) in Zeran and Toyota. Both companies were based on licences. The author shows, however, that the Japanese company, even at an early stage of its existence, took steps to build its own research and development potential, which made it independent of foreign technologies over time. It seems that from a teaching point of view, it would be important for students to understand why a similar process did not take place at FSO. This, however, would make it necessary to provide students with a wider range of information on the social capital of both companies, and first of all on the modernisation concepts implemented in Poland and Japan, to make a developmental leap. Then, the internal history of both companies could be used for a broader discussion on the effects of the implementation of government-imposed accelerated development programmes in countries lagging behind in relation to the West (Olejniczak, 2015).

The phenomenon of enterprise survival remains at the centre of interest of Karolina Mikołajewska-Zając, the author of a comprehensive, three-part study devoted to the Wedel company. The author shows how in the interwar period it transformed from a craft workshop into a large factory and gained its share of foreign markets, and then how the owners tried to provide employees with a relatively safe and dignified existence during the war. In the part devoted to the postwar period, the author writes about removing the former owners after the company's nationalisation, and tracks the fate of the brand and the trademark that have been preserved (for some time to be used only in foreign markets). She also tries 
to show that the fate of the factory was similar to the fate of other nationalised plants, and notes that thanks to the efforts of its personnel, the plant developed and managed to maintain some kind of personal continuity with the pre-war period, as the pre-war staff remained in important positions. The system of real socialism is described as hampering the development possibilities of the company, and, in an interesting way, the study looks behind the scenes: it describes planning tenders, informal efforts to obtain foreign currency for investments, or the exchange of goods for goods with other plants during the worst crisis of the 1980s. She also writes about the decapitalisation of the machine park caused by investment restrictions in the last decade of the Polish People's Republic and the state in which Wedel entered the transformation period. The author draws a picture of disputes over the privatisation of the company, writes about different attitudes of various company's stakeholders to potential foreign investors, describes the changes in managed structures that occurred when the Pepsico company became the owner of Wedel, emphasises the elements of continuation-allowing the managers involved in running the company for decades to keep their positions, and expects students to reflect on the consequences of a gradual change of management structures. She also follows the history of the dispute with the Wedel family about the right to use the brand. She looks at the process of systemic transformations and ownership transformations through the eyes of the employees, based on interviews conducted with them. This is a critical look, especially in reference to the period when Cadbury became the owner of the Warsaw Wedel factory. It began to rely on subcontractors in its production, which threatened traditional tastes and recipes, and it reduced employment; it then started hiring employees through a temporary employment agency, as well as attempting to transfer production to Wrocław (Mikołajewska-Zając, 2016a, 2016b, 2016c).

The study devoted to the pencil factory of Stanisław Majewski in Pruszkow also illustrates well the interest in long-term business survival. It describes how the company collapsed several times, yet it managed to be reborn each time. First, according to the corporate story, it was destroyed almost completely by German artillery during World War I. The remains of the plant were evacuated to the depths of Russia, where production was resumed, but the factory's assets were then seized by the Bolsheviks. The founder rebuilt the company in the early 1920s thanks to loans from public funds, and then modernised and transformed it into a joint-stock company. World War II again forced the plant to reduce production, and the company manager at the time, Leszek Majewski, the son of the founder, had to sell his house to be able to pay wages to the employees. The story of war is, in this case, as with the studies of the Jabłkowski Brothers and Wedel, a story of solidarity: the director fictitiously employs people threatened with arrest by the Germans and helps citizens of Warsaw who had been banished from the city after the uprising. The author sees the element of continuation in the fact that the plant was re-launched after the war by the pre-war personnel. They also formed the factory management after it was nationalised and the former owners were not allowed to enter its premises. The development of the social functions of the company and its actions for the benefit of the city in the 1960s (which were, in fact, 
a feature characterised by the entire Polish industry) are also seen as the continuation of activities related to corporate social responsibility conducted in the interwar period (Olejniczak, 2016).

\section{Conclusions}

The number of examples of American teaching materials whose authors make an effort to draw students' attention to important social or economic processes, not focusing solely on managerial decisions, is small. Therefore, business history as it is presented to Harvard students should be considered an area of untapped opportunity. The course does not promote active social attitudes, does not sensitise the students to injustices and inequalities, does not warn about their consequences, and does not use its potential in explaining the genesis of the present day.

Both the subject matter of the classes and the way the subject is presented in teaching materials are strongly connected with the tradition of practising business history as a science. It originated from the interest in biographies of outstanding entrepreneurs and the writing of corporate stories. Thus, placing emphasis on biographical themes and the history of large companies in the university classes that are taught should not be surprising.

Business history in the United States (but also in other parts of the Western world) is mainly cultivated in the Departments of Management or by historians employed in public museums, most often specialising in the history of industry and technology, as well as museums created by large companies. These institutional conditions make business historians prone to present competition and individual entrepreneurship as factors of social progress. Globalisation processes appear to lead to an increase in labour productivity, an unprecedented acceleration of technology development, and an improvement of living conditions (McCraw, 2000). The course of business history becomes, in effect, a great praise of the free market. There is not much room for caring about those who lose in this market.

History is an idiographic science. The power of historical narrative consists in presenting the phenomena of social life in their wealth and nuance. Management sciences, in turn, have a nomothetic character, seeking rules and regularities. Management sciences also have a practical dimension, as they must respond to the needs of business people seeking simple, universal recipes for success. History harnessed in the service of management restrains its pursuit of the wealth of description and the capturing of nuance. Case studies prepared on the basis of historical material are designed to develop students' ability to solve problems in practice, tell them how to act in a specific situation. These case studies should provide students with the skills and know-how that allow them to respond to threats or take advantage of opportunities, not know-why, allowing them to explain the causes and fully understand complicated economic processes (cf. Górski, 2011, p. 28). The description of social reality is usually of a sketchy nature, so it does not open up a field for discussion 
about corporate social responsibility or moral dilemmas behind strategic decisions. It is this reductionism that means that the educational potential of this material and the classes in which it is discussed are not fully exploited.

The authors of the Polish case studies show a high level of methodological awareness as researchers. In their theoretical studies (which they readily undertake), they write that corporate stories are discursive, that these stories change character depending on who tells them and in what circumstances, and that they can serve different purposes, for example, building a positive brand image. However, this aspect is often forgotten in the teaching materials, although some simplifications are inevitable in case studies for students. There is no reason, however, for the uncritical repetition of narratives created by (former) owners or placed in celebratory publications. One of the practical benefits of history education in the case of future managers could be to teach them what historians call source criticism: asking the right questions with regard to documents, comparing documents, and reconstructing the course of events on the basis of the sometimes incomplete, contradictory or distorted information contained within them. The ability to acquire information and correctly interpret data in a situation of information noise or information deficiency is important in managerial practice. Unfortunately, some of the Polish case studies teach more how a document should not be treated. None of these case studies really give students an opportunity for direct contact with the original source or teach them to analyse it. It is also worth noting that the goals that the authors of historical case studies want to achieve through their use are often limited: case studies are used to teach the application of analytical tools, such as the Value Proposition Canvas or the Ishikawa fishbone diagram. The fact that the materials on the basis of which students should practise these skills relate to historical reality is of little importance in this case.

The analysis of the Polish case studies also shows a clear divergence of research from teaching practice. An important topic of research conducted by Polish management specialists who take into account the historical perspective is the transformation of socialist enterprises into capitalist enterprises. Additionally, there are also important sociological and anthropological studies describing the transition to the market economy from the perspective of a single company and the people associated with it (e.g.: Dunn, 2008).

Despite this, none of the case studies ask questions about the social consequences of the transformation. Meanwhile, it seems that it is difficult to understand the socio-economic problems of contemporary Poland and the functioning of today's peripheral or semi-peripheral capitalism in our country without the knowledge of how enterprises operated in the system of real socialism and how the systemic change occurred. The spread of the attitude of learnt helplessness, the formation of poverty enclaves, and the delegitimisation of a market economy in the eyes of significant groups of Polish society are phenomena that still affect the situation in which Polish entrepreneurs are operating. The origins of the propensity for the paternalistic treatment of employees, problems with work ethics or difficulties in institutionalising relations between employers and employees can also be sought in the historical heritage. However, the Polish case studies do not describe the transfor- 
mation period in a way that enables future managers to better understand the environment in which they will operate, and the period of the centrally managed economy is ignored or described in extremely simplified terms with reference to the totalitarian paradigm: the system of real socialism is portrayed as either oppressive or absurd, while the company management, side by side with the employees (and in any case the key members of the personnel), tries to work "normally" under these conditions, i.e. in a way as close as possible to market rules. This is a Polish echo of Chandler's assumption about the natural character and not only the economic but also the moral superiority of the free market system over any other economic system. The echo of the Chandlerian approach to history is also evident in the selection of topics for Polish studies, the conviction that students should learn primarily about the successes of outstanding managers. In Poland, it may also be a result of the existence among the intellectual elites (also encompassing the authors of such studies) of the awareness of a civilisational distance in relation to the West and attempts to seek exaggerating examples in the past which show that large, modern, wellmanaged companies, whose owners did not forget about the needs of their employees and other stakeholders in the pursuit of profit, operated in Poland.

\section{References}

Barker, T. C., Campbell, R. H., \& Mathias, P. (1960). Business history. London: The Historical Association.

Chandler, A. D. (1962). Strategy and structure. Chapters in the history of the industrial enterprise. Cambridge-London: MIT Press.

Chandler, A. D. (2002). The visible hand. The managerial revolution in American business. Cambridge-London: The Belknap Press of Harvard University Press.

Chłopecki, J. (1999). Nauki humanistyczne - potrzebne czy zbędne? Zeszyty Naukowe Wyższej Szkoły Informatyki i Zarzadzania w Rzeszowie, 4, 7-20.

Colli, A. (2003). The history of family business 1850-2000. Cambridge: Cambridge University Press.

Duda, J. (2008). W kręgu paradygmatu historyzmu (o zmieniającej się roli refleksji historycznej w myśli ekonomicznej. In J. Skodlarski (Ed.), Historia gospodarcza i historia myśli ekonomicznej a teoria ekonomii (pp. 18-29). Łódź: Wydawnictwo Uniwersytetu Łódzkiego.

Dunn, E. (2008). Prywatyzujac Polskę. O bobofrutach, wielkim biznesie i restrukturyzacji pracy. Warsaw: Wydawnictwo Krytyki Politycznej.

Feldman, G. D. (2001). Allianz and the german insurance business 1933-1945. Cambridge: Cambridge University Press.

Galambos, L. (1967). American business history. Washington: Service Center for Teachers of History.

Górski, P. (2007). Perspektywa historyczna w teorii i badaniach w dziedzinie organizacji zarządzania. Wspótczesne Zarządzanie, 4, 20-28. 
Górski, P. (2009a). Menedżerowie, ich władza i wiedza w perspektywie ideologicznej. In P. Górski (Ed.), Humanistyka $i$ zarządzanie. $W$ poszukiwaniu problemów badawczych $i$ inspiracji metodologicznych (pp. 43-56). Kraków: Wydawnictwo Uniwersytetu Jagiellońskiego.

Górski, P. (2009b). Zarządzanie w perspektywie humanistycznej. Organizacja i Kierowanie, 4, 107-121.

Górski, P. (2011). Kształcenie menedżerów wobec zjawiska kryzysu. Perspektywa historyczna. Master of Business Administration, 6, 25-35.

Jastrząb, M. (2011). Historia biznesu: czego uczy i czy pomaga zrozumieć światowy kryzys? Master of Business Administration, 6, 36-47.

Jastrząb, M. (2013). Problematyka społecznej odpowiedzialności w nauczaniu historii biznesu w Harvard Business School. Annales. Ethics in Economic Life, 16, 63-74.

Jeremy, D. J., \& Tweedale, G. (2005). Introduction. In D. J. Jeremy \& G. Tweedale (Eds.), Business history. London: Sage.

Jones, G., \& Brown, A. (2011). Thomas J. Watson, IBM and Nazi Germany (HBS Case Study 9-807-133). Boston: Business School Publishing.

Jones, G., Bud-Freirman, L. (2010). Weetman Pearson and the Mexican oil industry (HBS Case Study 9-804-085). Boston: Harvard Business School Publishing.

Jones, G., \& Fernandes, F. T. (2012). The Guggenheims and Chilean nitrates (HBS Case Study 9-810-141). Boston: Harvard Business School Publishing.

Jones, G., \& Ishna, H. B. (2012). Rupert Murdoch, The Last Tycoon (HBS Case Study 9-811-017). Boston: Harvard Business School Publishing.

Jones, G., \& Lubinski, C. (2011). Willi Jacobsohn and Beiersdorf: Managing expropriation and anti-semitism (HBS Case Study 9-811-060). Boston: Harvard Business School Publishing.

Jones, G., \& von Siemens, B. (2011). Werner von Siemens and the Electric Telegraph (HBS Case Study 9-811-004). Boston: Harvard Business School Publishing.

Kluska, R. (1999). Miejsce nauk społeczno-humanistycznych w kształceniu menedżerów. Zeszyty Naukowe Wyższej Szkoły Informatyki $i$ Zarzadzania $w$ Rzeszowie, 4, 201-214.

Koehn, N. F., Dwojeski, A. E., Grundy, W., Helms, E., \& Miller, K. (2011). Madam C.J. Walker: Entrepreneur, leader and philanthropist (HBS Case Study 9-807145). Boston: Harvard Business School Publishing.

Koehn, N. F., \& Miller, K. (2010). John D. Rockefeller and the creation of the Standard Oil (HBS Case Study 9-807-010). Boston: Harvard Business School Publishing.

Koehn, N. F., Miller, K., \& Wilcox, R. K. (2011). Bono and U2 (HBS Case Study 9-809148). Boston: Harvard Business School Publishing.

Koplan, A. M., \& Jones, G. (2011). Vehbi Koc and the making of Turkey's largest business group (HBS Case Study 9-811-081). Boston: Harvard Business School Publishing.

Koźmiński, A. K., \& Latusek-Jurczak, D. (2011). Rozwój teorii organizacji. Od systemu do sieci. Warsaw: Wolters Kluwer.

Ludescher, M., \& Burgelman, R. A. (2012). DKSH in 2011. Stanford Graduate School of Business, Case SM 204.

Marks, B., \& Skodlarski, J. (1995). Uwagi dotyczące nauczania historii na kierunkach ekonomicznych. Studia Prawno-Ekonomiczne, 52, 223-240. 
Matera, R. (2006). Czy odwrót od historii? In J. Skodlarski (Ed.), Z historii myśli ekonomicznej $i$ historii gospodarczej. Ksiega jubileuszowa prof. Wiestawa Piątkowskiego (pp. 93-105). Łódź: Wydawnictwo Uniwersytetu Łódzkiego.

Maurer, N. (2011). Dubai in crisis (HBS Case Study, 9-710-061). Boston: Harvard Business School Publishing.

McCraw, T. K. (1999). Teaching history courses to Harvard MBA students: Building enrollment from 21 to 1,300. Business and Economic History, 28(2), 153-162.

McCraw, T. K. (2000). American business 1920-2000. How it worked. Arlington Heights: Harlan Davidson.

Mead, J., Wicks, A. C., \& White, H. (2010). Chiquita in Columbia. Charlottesville: University of Virginia, Darden School Foundation.

Mikołajewska, K. (2014). Alienation and rush towards change: introducing capitalism to a state-owned polish enterprise. Oral History, Autumn, 69-80.

Mikołajewska-Zając, K. (2016a). Historia zakładów E. Wedel (1851-1945): firma rodzinna. $\quad \mathrm{http} / / /$ studiumprzypadku.edu.pl/images/studiumprzypadku/050cWedel_case_1-Ok_20_12_2017.pdf

Mikołajewska-Zając. K. (2016b). Historia zakładów E. Wedel (1944-1989): Zjednoczenie Przemystu Cukierniczego. http://studiumprzypadku.edu.pl/images/studiumprzypadku/051c-Wedel_case_---2-Ok_20_12_2017.pdf

Mikołajewska-Zając. K. (2016c). Historia Zakładów E. Wedel (1989-2011): korporacja. http://studiumprzypadku.edu.pl/images/studiumprzypadku/043c-Wedel_case_3A-3BOk_20_12_2017.pdf

Mikołajewska-Zając, K. (2017). Zwrot historyczny w teorii organizacji: splatając ważne wątki w badaniach nad praktykami pamięci organizacyjnej. Studia Socjologiczne, $2(225), 45-72$.

Mikołajewska-Zając, K., \& Wawrzyniak, J. (2016). Nostalgia jako narzędzie krytyki transformacji. Mit dobrego właściciela w opowieściach pracowników fabrycznych. Przegląd Socjologii Jakościowej, 12(2), 36-54.

Morawski, W. (2008). Czy historia gospodarcza jest jeszcze potrzebna. In J. Skodlarski (Ed.) Historia gospodarcza i historia myśli ekonomicznej a teoria ekonomii. Łódź: Wydawnictwo Uniwersytetu Łódzkiego.

Ochinowski, T. (2005). Metoda historyczno-psychologiczna w zarządzaniu - zarys koncepcji oraz przykład programu badań. Studia $i$ Materiały - Wydział Zarzadzania Uniwersytetu Warszawskiego, 1, 7-20.

Ochinowski, T. (2013). Tradycje przedsiębiorczości w Polsce jako źródto kapitalu kulturowego organizacji. Warszawa: Wydawnictwo Naukowe Wydziału Zarządzania Uniwersytetu Warszawskiego.

Ochinowski, T. (2017). Przypominanie organizacyjne jako kompetencja. Problemy Zarządzania, 2(68), 39-53.

Olejniczak, T. (2015). FSO vs Toyota. http://studiumprzypadku.edu.pl/images/studi umprzypadku/027c-FSO-vs-Toyota_czesc-A_CASE-i-B-Ok_20_12_2017.pdf

Olejniczak, T. (2016). Niezłomny: historia firmy St. Majewski. http://studiumprzypad ku.edu.pl/images/studiumprzypadku/017c-Bambino_case-Ok_20_12_2017.pdf 
Olejniczak, T., \& Pikos, A. (2017). Przerwana historia Domu Towarowego Braci Jabłkowskich. http://studiumprzypadku.edu.pl/images/studiumprzypadku/040c -Jablkowscy_caseOk_20_12_2017.pdf

Olejniczak, T., \& Przystupa-Rządca, K. (2016). FASING: lańcuch historii. http://studiumpr zypadku.edu.pl/images/studiumprzypadku/032c-FASING_case-Ok_20_12_2017.pdf

Pikos, A., \& Olejniczak, T. (2017). Business history in Poland: Current state and future potential. Journal of Management and Business Administration. Central Europe, 3, $55-77$.

Ratajczak, M. (2011). Wyższe szkolnictwo ekonomiczne w Polsce wobec wyzwań kryzysu. Master of Business Administration, 19(6), 14-24.

Rowlinson, M., Jacques, R. S., \& Booth, C. (2009). Critical management and organizational history. In M. Alvesson, T. Bridgeman, \& H. Willmott (Eds.), Oxford handbook of critical management studies. doi: 10.1093/ oxfordhb/9780199595686.013.0014.

Sobczak, T. (2010). Polskie doświadczenia w badaniach organizacji i zarządzania w perspektywie historycznej. Współczesne Zarzadzanie, 3, 113-123.

Starostka, J., Olejniczak, T., \& Pikos, A. (2016). Ćmielów: z tradycją w nowoczesność. http://studiumprzypadku.edu.pl/images/studiumprzypadku/042c-Cmielow_case-Ok _20_12_2017.pdf

Turner, H. A. (2005). General Motors and the Nazis. The struggle for control over Opel, Europe's biggest carmaker. New Haven-London: Yale University Press.

Usselman, S. W. (2006). Still visible: Alfred D. Chandler's "The Visible Hand." Technology and Culture, 47(3), 584-596.

Witek-Crabb, A. (2017). Długowieczność organizacji. W poszukiwaniu czynników trwałości rozwoju. Handel Wewnętrzny, 3(368), 157-167.

http://www.hbs.edu/businesshistory/curriculum.html 